\title{
A Case for the Continued Study of the Golden Mussel Invasion of Brazil: Efficient Detection and Containment of Limnoperna fortunei (Dunker, 1857) Dispersion Involves Multiple Approaches and Different Actors
}

\author{
Rayan Silva de Paula ${ }^{1,2 *}$, Mariana de Paula Reis ${ }^{1,2}$, Gabriela Rabelo Andrade ${ }^{2}$, Clara Carvalho e Souza ${ }^{1,2}$, \\ Antonio Valadão Cardoso ${ }^{2,3}$ and Erika Cristina Jorge ${ }^{1}$ \\ ${ }^{1}$ Departamento de Morfologia, Universidade Federal de Minas Gerais (UFMG), Minas Gerais, Brazil \\ ${ }^{2}$ Centro de Bioengenharia de Espécies Invasoras de Hidrelétricas (CBEIH), Minas Gerais, Brazil \\ ${ }^{3}$ Escola de Design, Universidade do Estado de Minas Gerais (UEMG), Minas Gerais, Brazil
}

Submission: March 10, 2021; Published: May 19, 2021

Corresponding author: Rayan Silva de Paula, Universidade Federal de Minas Gerais, Avenida Presidente Antônio Carlos, 6627 - Pampulha, Belo Horizonte - MG, 31270-901, Brazil Email: rayansdpaula@gmail.com

\begin{abstract}
The establishment of invading organisms in natural ecosystems is one of the most serious environmental issues. In Brazil, the invasive species Limnoperna fortunei (Dunker, 1857), the golden mussel, is a mollusk capable of causing major changes in water systems, generating social and economic impacts, given its biofouling capacity. Limnoperna fortunei can easily block pipes and heat exchangers in the water systems of hydroelectric power plants due to its ability to strongly adhere to the substrate using its byssus - a bundle of filaments secreted by these animals. Therefore, the early detection of this invader is essential for management actions to be immediate, in order to control population growth rate at the beginning of the invasive process, preventing this environment from serving as a source for new infestations. The implantation of a method that integrates the active monitoring of prioritized areas, laboratory techniques, including molecular biology methods, and the sharing of hydrographic data between basin managers and users for early detection of the presence of species in Brazilian waters appears as an efficient option to prevent and control invasions.
\end{abstract}

Keywords: Limnoperna fortunei; Golden mussel; Invasive species; Early detection; Molecular biology; Biofouling; Economic losses

\section{Introduction}

Biological invasions by alien species provoke ecosystem imbalance, thus affecting the anthropic use of natural resources [1]. Limnoperna fortunei (Dunker, 1857), popularly known as the golden mussel, is an example of an invasive species. This bivalve mollusk belongs to the Mytilidae Family (Subclass Pteriomorpha, and Order Mytiloida), native to Southeast Asia and was first introduced to South America in 1990, probably via ballast waters from ships on commercial routes [2,3]. Specifically, in Brazil, the golden mussel is established in the South, Southeast, Pantanal biome and, more recently, its presence was reported in the Northeast region, on the border between the states of Bahia and Pernambuco [4,5].
Morphophysiological aspects of the golden mussel guarantee its success as an invasive species: (1) they are protected by two valves (shells), composed of calcium carbonate, which support the soft body and provide protection against external agents [6,7]; (2) they are prolific filter feeders, as the clearance rates for the golden mussel are among the highest reported for suspension feeding bivalves, comparable to other invasive species such as Dreissena polymorpha (Pallas, 1771), Dreissena bugensis (Andrusov, 1897) and Corbicula fluminea (Müller, 1774) [8]; (3) they are gonochoric animals (rare hermaphroditism events were previously confirmed), with external fertilization and indirect development $[6,9]$. The L. fortunei gonads present cyclic maturation stages that 
may vary according to the season, and can be divided into four stages: regression, spawning, development, and regeneration. The individual becomes an adult after a period of approximately one year, thus reaching sexual maturity.

However, the spawning phase was observed in the female, only during the summer months, a time when the water temperature reaches its highest point [9]. Due to the large quantity of larvae released into the water they make excellent candidates for promoting new invasions, not only because of their large numbers but also because of their microscopic size [10]. Several countermeasures and anti-fouling treatments have been proposed to mitigate $L$. fortunei macrofouling observed in industrial plants [11-13]. The physical (eg, backwashing) and chemical (e.g., tannins and chlorine) antifouling methods are the most used, however, they still lack specific regulation by the Brazilian environmental agencies, besides the high implantation costs and uncertainty on their efficiency and the impact of their prolonged use [14]. Thus, the early detection of L. fortunei in the environment is essential to control the spread while the populations are still small enough to be eradicated, minimizing the chances of success of the invasion [15].

In addition, early detection allows the establishment of sanitary barriers to prevent the invasion of new environments. However, larval identification of $L$. fortunei by microscopic evaluation can be difficult since species-specific morphological characters only appear in the latest stages of the development [16]. Though some of the developmental stages of the larvae can also resemble those of other mollusk species which may lead to inconclusive results in some cases. Molecular biology emerges as a powerful tool that assists in early detection, species identification, and the monitoring of invaded and non-invaded areas. Since 2006, when Pie et al. designed the primer set for amplification of Cytochrome C Oxidase Subunit I (COI) gene for L. fortunei DNA barcoding, much progress has been made towards molecular approaches targeting the golden mussel [17].

Including population variability studies, establishment of advanced techniques for detecting and releasing golden mussel 'omics' (genomes, transcriptomes and proteomics), and the perspective of genetic editing with the CRISPR/Cas9 system. The compendium of molecular information from $L$. fortunei was assembled in the review published by de Paula et al. (2020), which presents a concise timeline highlighting the state-of-theart research regarding the molecular aspects of L. fortunei [18]. Recently, Ludiwig et al. (2021) evaluated the haplotype network of the Brazilian golden mussel populations, focusing on the population of the Northeastern of Brazil, in an attempt to outline the possible invasion routes used by L. fortunei. This review of the possible invasion routes has emphasized the need for the creation of stricter sanitary barriers. The main concern of these latter authors is the risk of arrival of the golden mussel in the Amazon basin [19].
The presence of the golden mussel in Brazil and other South American countries has been linked to several economic and environmental impacts. Among the environmental impacts, the presence of $L$. fortune $i$ is related to processes such as cyanobacterial blooms, nutrient recycling, and increased transparency of the water column [1]. Economically, the macrofouling resulting from the establishment of the golden mussel in water cooling and abstraction pipes and systems in hydroelectric plants generates high maintenance and operation costs [20]. This fouling ability is related to the production of byssus threads, a bundle of filaments secreted by glands located on the foot of $L$. fortunei. The formation of byssus is extremely organized, synchronized, complex and rapid, involving the presence of vesicles containing collagen in the liquid crystal phase, which seem to be used in the assembly of these filaments [21].

Despite the damage resulting from the L. fortunei invasion, the biological study and monitoring of such invasions brings many benefits. In fact, researchers, institutes, and industries are increasingly interested in discovering and developing new technologies, patents and products based on the careful observation of the biofouling process, such as the synthesis of purified bioadhesives from mussels and other organisms [22,23].

\section{Conclusion}

Can the answers to biological invasions be found within the invasions themselves? Are we able to gain enough knowledge from studying these invaders to begin to see the benefits as well as the consequences of their invasions? It may be impossible to find the answers to the questions these invaders pose without the right funding, resources, and technologies. By recognizing that this is a problem worthy of study and resources we have already taken the first step in solving it. First, we must characterize the ecological and biological aspects of the golden mussel only then can we propose antifouling strategies which are specific in their abilities to combat this invasion process whilst maintaining the ecosystem balance within these environments.

Over the years, much progress has been made, in different frontiers of knowledge, with regard to the characterization of the mechanisms involving L. fortunei. Many hydroelectric plants, the main industrial sector which suffers directly from the invasion of the golden mussel, have adapted to the presence of this mollusk in their facilities. They have been forced to create alternatives to establish minimally and economically viable coexistence strategies. Regardless of the approach used, many of the proposed solutions were achieved due to the effort of researchers who persist in understanding the phenomena that revolve around the invasion of L. fortunei. However, there is an important caveat here: the discord between the timelines of scientific discovery which oftentimes moves at a slow and steady pace, and the urgency with which these solutions need to be implemented to combat the problems industries are facing on a daily basis can often result in 
tension between two groups who are working towards the same goal.

After a large volume of data, information and responses are obtained, it is necessary to make certain that this knowledge is not restricted to researchers and industrial managers but be disseminated to society at large. This information is especially impactful in the hands of those directly involved with aquaculture, such as fishermen's associations, small and medium-sized farmers and even tourist activities, which for lack of information, can transport the golden mussel to an area that has not yet been invaded. Thus, it is important that incentives for studies on the biology of invasions include environmental education and scientific divulgation activities which may reach a wider proportion of those coming into contact with the golden mussel, oftentimes without realizing.

The fact is when it comes to biological invasions prevention is better than cure. Whilst these invaders can promote the creation of new areas of study and new technologies the economic impacts, they can generate can be incredibly detrimental to communities facing them. The mobilization and formation of work groups and task forces, which have diverse profiles and professionals, and integrate different areas of knowledge in multidisciplinary approach (currently, in addition to the classical areas, there is a movement of areas involving computing, engineering, mathematics and robotics, corroborating the mitigation of macrofouling), become essential for decision-making in the face of biological invasion. Therefore, it is important to continuously invest and promote research that increases the understanding of the morphophysiological, genetic, developmental, and ecological aspects of $L$. fortunei, in order to obtain a holistic view of the invasion process caused by this mollusk.

\section{Acknowledgements}

This work was supported by the Companhia Energética de Minas Gerais (CEMIG) - R\&Ds ANEEL GT-0604. Erika Cristina Jorge received a scholarship from Conselho Nacional de Desenvolvimento Científico e Tecnológico (CNPq). Our thanks to Emma Jones for proofreading this article.

\section{References}

1. Boltovskoy D \& Correa N (2015) Ecosystem impacts of the invasive bivalve Limnoperna fortunei (golden mussel) in South America. Hydrobiologia 746(1): 81-95.

2. Pastorino G, G Darrigran, S Martin, L Lunaschi (1993) Limnoperna fortunei (Dunker, 1857) (Mytilidae), nuevo bivalvo invasor en aguas del río de La Plata. Neotropica La Plata 39(101/102): 34.

3. Darrigran G (1995) Limnoperna fortunei: Um problema para los sistemas naturales de agua dulce del Mercosur? Revista Museo La Plata La Plata 1(5): 85-87.

4. Boltovskoy D, Correa N, Cataldo D, Sylvester F (2006) Dispersion and ecological impact of the invasive freshwater bivalve Limnoperna fortunei in the Río de la Plata watershed and beyond. Biological Invasions 8(4): 947-963.
5. Barbosa NP, Silva FA, de Oliveira MD, dos Santos Neto MA, de Carvalho MD, et al. (2016) Limnoperna fortunei (Dunker, 1857)(Mollusca, Bivalvia, Mytilidae): first record in the São Francisco River basin, Brazil. Check List 12(1): 1846.

6. Morton B (1977) Freshwater fouling bivalves. In Proceedings of the First International Corbicula Symposium, held at Texas Christian University, Fort Worth, Texas, pp. 1oe14.

7. Nakamura Filho A, Almeida ACD, Riera HE, Araújo JLFD, Gouveia VJP, et al. (2014) Polymorphism of $\mathrm{CaCO} 3$ and microstructure of the shell of a Brazilian invasive mollusc (Limnoperna fortunei). Materials Research 17L 15-22.

8. Sylvester F, Dorado J, Boltovskoy D, Juárez Á, Cataldo D (2005) Filtration rates of the invasive pest bivalve Limnoperna fortunei as a function of size and temperature. Hydrobiologia 534(1): 71-80.

9. Dei Tos C, Quagio-Grassiotto I, Sarah Mazzoni T (2016) Cellular development of the germinal epithelium during the gametogenic cycle of the golden mussel Limnoperna fortunei (Bivalvia: Mytilidae). Rev Biol Trop 64(2): 521-536.

10. Darrigran G, Mansur MCD (2006) Distribución, abundancia y dispersión. In: G Darrigran, C Damborenea (Eds). Bio-invasión del mejillón dorado en el continente americano. La Plata, EDULP, P. 226.

11. Fusetani N (2004) Biofouling and antifouling. Nat Prod Rep 21(1): 94104.

12. Durr S, Watson DI (2010) Biofouling and antifouling in aquaculture. Biofouling 267-287.

13. Cristiani P, Perboni G (2014) Antifouling strategies and corrosion control in cooling circuits. Bioelectrochemistry 97: 120-126.

14. Silva APDS, Dias HCT, Bastos RKX, Silva E (2009) Qualidade da água do reservatório da Usina Hidrelétrica (UHE) de Peti, Minas Gerais. Revista Arvore, 33(6): 1063-1069.

15. Vander Zanden MJ, Olden JD (2008) A management framework for preventing the secondary spread of aquatic invasive species. Canadian Journal of Fisheries and Aquatic Sciences 65(7): 1512-1522.

16. Garland E D, Zimmer C A (2002) Techniques for the identification of bivalve larvae. Marine Ecology Progress Series 225: 299-310.

17. Pie MR, Boeger WA, Patella L, Falleiros RM (2006) A fast and accurate molecular method for the detection of larvae of the golden mussel Limnoperna fortunei (Mollusca: Mytilidae) in plankton samples. Journal of Molluscan Studies 72(2): 218-219.

18. de Paula RS, de Paula Reis M, de Oliveira Junior RB, Andrade GR, de Carvalho MD, et al. (2020) Genetic and functional repertoires of Limnoperna fortunei (Dunker, 1857)(Mollusca, Mytilidae): a review on the use of molecular techniques for the detection and control of the golden mussel. Hydrobiologia 847(10): 2193-2202.

19. Ludwig S, Sari EHR, Paixão H, Montresor LC, Araújo J, et al. (2021) High connectivity and migration potentiate the invasion of Limnoperna fortunei (Mollusca: Mytilidae) in South America. Hydrobiologia 848(2): 499-513.

20. Nakano D, Strayer DL (2014) Biofouling animals in freshwater: biology, impacts, and ecosystem engineering. Frontiers in Ecology and the Environment 12(3): 167-175.

21. Renner-Rao M, Clark M, Harrington MJ (2019) Fiber formation from liquid crystalline collagen vesicles isolated from mussels. Langmuir 35(48): 15992-16001.

22. Harrington MJ, Jehle F, Priemel T (2018) Mussel byssus structurefunction and fabrication as inspiration for biotechnological production of advanced materials. Biotechnology Journal 13(12): 1800133. 
23. Davey PA, Power AM, Santos R, Bertemes P, Ladurner P, et al. (2021) Omics-based molecular analyses of adhesion by aquatic invertebrates. Biol Rev Camb Philos Soc 96(3): 1051-1075.

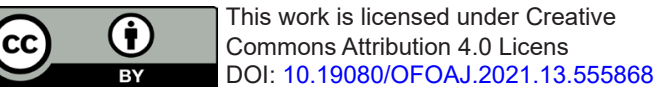

Your next submission with Juniper Publishers will reach you the below assets

- Quality Editorial service

- Swift Peer Review

- Reprints availability

- E-prints Service

- Manuscript Podcast for convenient understanding

- Global attainment for your research

- Manuscript accessibility in different formats

( Pdf, E-pub, Full Text, Audio)

- Unceasing customer service

Track the below URL for one-step submission https://juniperpublishers.com/online-submission.php 